\title{
Political Institutions, Economic Liberty, and the Great Divergence
}

Gary W. COX

I argue that Europe's political fragmentation interacted with her political innovations - self-governing cities and national parliaments - to facilitate "economic liberty," which in turn unleashed faster and more inter-connected urban growth. Examining urban growth over the period 600-1800 CE throughout Eurasia, I show that inter-city growth correlations were positive and significant only in Western Europe after $1200 \mathrm{CE}$. Within Western Europe, I show that growth correlations were greatest in the most fragmented and parliamentary areas, individual cities became significantly more tied to urban growth when their realms became parliamentary, and spillover effects (due to competition between rulers) were significant.

Some prominent explanations of Europe's economic divergence from $\checkmark$ the rest of the world highlight the continent's unique political institutions. Max Weber proposed that politically autonomous cities were "critical to Europe's economic rise, because [they] allowed for the provision of secure property rights free from the ambitions of princely rulers" (Stasavage 2014, p. 337). Other institutionalists have argued that parliaments were key to Europe's rise, because they too protected property rights against grasping monarchs (North and Weingast 1989; De Long and Shleifer 1993; Acemoglu et al. 2005). Skeptics have countered that both town councils and national parliaments were prone to capture by rent-extracting special interests, thereby impeding development (Epstein 2000; Volckart 2002; Stasavage 2014; Ogilvie and Carus 2014).

Another explanation holds that Europe's persistent political fragmentation drove the continent's divergence, by increasing merchants' exit options and forcing rulers to compete (Baechler 1975; Landes 1999; Jones 2003; Vaubel 2008). Skeptics have countered that fragmentation also fostered over-taxation, free riding, and endemic warfare, all bad for development (Rosenthal 1992; Epstein 2000; Rosenthal and Wong 2011).

The Journal of Economic History, Vol. 77, No. 3 (September 2017). (C) The Economic History Association. All rights reserved. doi: 10.1017/S0022050717000729

Gary W. Cox is the William Bennett Munro Professor, Department of Political Science, Encina Hall West, Suite 100, Stanford University, Stanford, CA 94305. E-mail: gwcox@stanford.edu.

I thank Avidit Acharya, Robert Bates, Lisa Blaydes, Mark Dincecco, Jim Fearon, Vicky Fouka, Phil Hoffman, Ken Scheve, and participants in the Comparative Workshop at Stanford and the Kim Thomas Interdisciplinary Lecture at Whittier College for their comments. I also thank Darin Christensen for programming assistance. 
In this article, I argue that Europe's political fragmentation interacted with her institutional innovations to foster substantial areas of "economic liberty," where European merchants could organize production freer of central regulation, faced fewer central restrictions on their shipping and pricing decisions, and paid lower tariffs and tolls than their counterparts elsewhere in Eurasia. When fragmentation afforded merchants multiple politically independent routes on which to ship their goods, European rulers refrained from imposing onerous regulations and levying arbitrary tolls, lest they lose mercantile traffic to competing realms. Fragmented control of trade routes magnified the spillover effects of political reforms. If parliament curbed arbitrary regulations and tolls in one realm, then neighboring rulers might have to respond in kind, even if they themselves remained without a parliament.

Greater economic liberty, fostered by the interaction of fragmentation and reform, unleashed faster and more inter-connected urban growth. To document this, I examine patterns of urban growth over the period 600-1800 CE in five major Eurasian regions: Western Europe, Eastern Europe, the Islamic World, East Asia, and South Asia. In a hypothetical world of perfectly free trade and no war, city growth rates should positively correlate with those of their trading partners. I show that inter-city growth correlations were statistically insignificant or negative throughout Eurasia in the period 600-1100 CE. After the twelfth-century wave of parliaments and communes began, however, Western Europeand Western Europe alone-exhibited strongly inter-connected urban growth.

Because the level of fragmentation and the activity of parliaments varied within Western Europe, we can learn more by focusing on this region. Extending the seminal work of Maarten Bosker, Eltjo Buringh, and Jan Luiten van Zanden (2013), I show that growth correlations were greatest in Europe's most fragmented and parliamentary areas. A difference-in-differences analysis shows that cities gaining representation not only grew faster but also became substantially more sensitive to urban growth in their environments. Reflecting the spillover effects of political reform, even non-parliamentary cities became more sensitive to urban growth, if enough of their neighbors became parliamentary. Moreover, these results were driven only by parliaments that wielded enough fiscal control to constrain the monarch. Collectively, my results provide new support for some classic institutionalist theses while stressing freer trade, rather than more secure property rights narrowly construed, as the key mechanism. 


\section{HOW POLITICAL FRAGMENTATION AFFECTED TRANSIT TAXES}

There has been much debate over whether Europe's political fragmentation created superior exit options, thereby promoting economic development, or instead spawned free riding and endemic warfare, thereby retarding economic development. ${ }^{1}$ To explore this issue, I begin by distinguishing two types of fragmentation that potentially affected European trade (cf. Shleifer and Vishny 1993).

Intra-route fragmentation split governing authority along a single shipping route, thereby inducing over-taxation of the common pool of merchants, as noted by Stephan Epstein (2000), Nicola Gennaioli and Hans-Joachim Voth (2011), and others. The canonical example is the Rhine River, where the original "robber barons" levied their infamous and excessive tariffs in the thirteenth century. In addition, intra-route fragmentation induced free riding in the provision of public goods such as security from bandits.

In contrast, inter-route fragmentation split rule across routes, thus enabling merchants to ship their products on multiple politically independent routes. In the rest of this section, I explore how inter-route (or exit-enhancing) fragmentation should have constrained the transit taxes competing rulers could levy. By transit taxes I mean all tariffs, tolls and fees that rulers charged merchants and merchandise traveling through their realms (and I use these terms interchangeably).

Consider two cities connected by $\mathrm{n}$ distinct land and water routes. Route 1 has the lowest physical cost of transporting merchandise $\left(c_{1}\right)$, route 2 has the next lowest cost $\left(\mathrm{c}_{2}\right)$, and so forth.

Assume that ruler 1 controls routes $1,2, \ldots$, e (the lowest-cost ones), but that routes $\mathrm{e}+1$ through $\mathrm{n}$ are controlled by competing princes (one prince per route). Let $\tau_{\mathrm{j}}$ be the tariff rate charged on route $\mathrm{j}$ and $\pi_{\mathrm{j}}$ be the perceived risk that the ruler operating route $j$ will impose confiscatory tariff surcharges. Merchants assess each route in terms of its total transport cost, $\mathrm{TTC}_{\mathrm{j}}$, which equals the sum of physical transport costs $c_{j}$, tariffs $\tau_{j}$, and the cost $g\left(\pi_{j}\right)$ of bearing a risk $\pi_{j}$ of confiscation. This last cost should have been especially heavy, given the medieval world's poorly developed capital markets. Expressing all costs as fractions of the unit sales price $p$, a merchant's net unit revenue is $\left(1-c_{j}-\tau_{j}-g\left(\pi_{j}\right)\right) p$. Profit maximization requires shipping on the lowest-TTC route.

\footnotetext{
${ }^{1}$ Vaubel (2008) provides a general survey of those attributing Europe's rise to the benefits of political fragmentation. Their arguments resonate with theoretical studies such as Tiebout (1956), Hirschman (1970), and Bates and Lien (1985). Among those stressing the costs of fragmentation are Rosenthal (1992), Epstein (2000), and Rosenthal and Wong (2011).
} 
Suppose all rulers are equally likely to confiscate $\left(\pi_{1}=\ldots=\pi_{\mathrm{n}}=\pi>\right.$ 0 ); all discount future payoffs identically; and all face negligible costs of maintaining their routes. In this symmetric world, ruler 1's optimal tariff rate $\tau_{1}^{*}$ will be set according to the following rule:

$$
\tau_{1}^{*}\left(c_{1}, \ldots, c_{n} ; e\right)=\left\{\begin{array}{l}
c_{e+1}-c_{1} \text { if } c_{e+1}-c_{1} \leq \tau_{\max } \& e<n \\
\tau_{\max } \text { else }
\end{array}\right.
$$

If ruler 1 controls all the routes or has a big enough cost advantage, then he will set tariffs to their revenue-maximizing level, $\tau_{\text {max }}$. However, when alternative routes exist that are both price-competitive and politically independent, the equilibrium tariff ruler 1 can charge declines. ${ }^{2}$

To illustrate the logic of this result, consider the Champagne Fairs. In the thirteenth century, these fairs constituted the premier European market for textiles, fur, leather, and spices. Late in the century, however, the Savoyards consolidated their grip on the Alpine passes, the King of France annexed the counties of Champagne and Brie, and both began raising transit fees. The Venetians and Genoese reacted by improving their galleys enough to make the sea trip to Bruges. In 1295 and 1300, the Count of Savoy lowered his tolls, in an effort to lure the Italians back (Spufford 2002, p. 166). But the sea route became safer and faster as the years passed, and the fairs were effectively defunct by 1350 (Abu-Lughod 1989, p. 71).

The coastal areas of Europe were naturally endowed with good harbors and afforded many sea routes with similar physical transport costs. The multiplication of European polities along the coasts should thus have entailed a substantial amount of exit-enhancing fragmentation. Moreover, coastal (as opposed to riverine) shipping was less exposed to redundant taxation by multiple rulers, unless there were narrow straits through which all ships had to pass. The net effect of political fragmentation should thus have been most favorable along Europe's coasts (and, similarly, along other Eurasian coasts with many natural harbors).

\section{HOW PARLIAMENTS AFFECTED TRANSIT TAXES}

Following Douglass North and Barry Weingast's (1989) seminal work on England's Glorious Revolution, many institutionalists have viewed parliaments as crucial mechanisms protecting property rights and, thus, promoting economic development. Critics, however, have questioned whether English property rights became more secure after the Revolution

\footnotetext{
${ }^{2}$ Formally, if $\mathrm{c}_{2}-\mathrm{c}_{1}<\min \left\{\tau_{\max }, \mathrm{c}_{\mathrm{n}}-\mathrm{c}_{1}\right\}$, then $\tau_{1}^{*}\left(\mathrm{c}_{1}, \ldots, \mathrm{c}_{\mathrm{n}} ; 1\right)<\tau_{1}^{*}\left(\mathrm{c}_{1}, \ldots, \mathrm{c}_{\mathrm{n}} ; \mathrm{n}\right)$.
} 
(for recent reviews, see Coffman, Leonard, and Neal 2013; Cox 2016) and argued that Europe's parliaments hindered economic development because they were prone to capture by rent-seeking interest groups (Ogilvie and Carus 2014). Here, I focus on a narrower issue - not whether parliaments protected property in general, but whether they protected merchants from high and arbitrary transit taxes.

Urban representatives should have opposed tariffs levied on domestic merchants. Indeed, the "abolition of tolls" was a prominent demand in Europe's earliest parliaments (Blockmans 1997, pp. 40-41) and communes (Lopez 1966, p. 265). While individual towns might have favored higher tariffs on foreign merchants, rulers would already have set revenue-maximizing tariffs and could veto further increases. Thus, tariffs in parliamentary realms should have been lower-and less arbitrary - than tariffs in non-parliamentary realms (North and Weingast 1989).

Creating a parliament in one realm should also have reduced the tariffs nearby rulers could charge. To illustrate, suppose that rulers 1 and 2 are symmetric, neither has a parliament, and $\mathrm{c}_{2}-\mathrm{c}_{1}<\tau_{\max }$. In this case, ruler 1 will set $\tau_{1}=c_{2}-c_{1}$. Now suppose prince 2 adopts a parliament which removes his ability to levy arbitrary surcharges. Merchants will now weigh ruler 1's physical cost advantage against his greater ability to confiscate. If $\mathrm{g}\left(\pi_{1}\right) \leq \mathrm{c}_{2}-\mathrm{c}_{1}$, then ruler 1's tariff rate will fall to $\mathrm{c}_{2}-\mathrm{c}_{1}-$ $g\left(\pi_{1}\right)$. If $g\left(\pi_{1}\right)>c_{2}-c_{1}$, then mercantile traffic will divert to route 2. Either way, political reform will affect the entire trading network, not just the realm in which it occurs.

Moreover, the spillover effects of political reform should increase with political fragmentation. The monarch of a large kingdom might not lower tariffs in response to the birth of a nearby parliament, since few domestic land routes would be exposed to competition. In contrast, rulers in highly fragmented areas faced competition all around. Thus, the effect of creating a parliament, at least one fiscally strong enough to extract concessions from the crown, should have more powerful ramifications in more fragmented areas.

\section{POLITICAL CONSTRAINTS ON PRINCELY REGULATION OF TRADE}

Political fragmentation and representative institutions can combine to improve another component of economic liberty - merchants' freedom to choose their own shipping routes and set their own prices. To illustrate, I compare the Ottoman Empire's travel restrictions and price controls with those in parliamentary England. 
Long-distance land trade in the Ottoman Empire was conducted on caravan routes "under the strict supervision of the Sublime Porte...The caravans had to follow the officially assigned routes and pay customs duties at the customs centers on their way. [T] he merchants [carried] a document eda tezkeresi, showing that they had paid all the incumbent taxes" (Bulut 2001, pp. 49, 52). In addition, merchants had to comply with the omnipresent price controls imposed by the sultan (Bulut 2001, pp. 36, 47).

In contrast, the English crown "did not claim-or at least claim successfully - a general jurisdiction to regulate prices" (Harvey 2005, p. 767). Nor did the crown usually regulate the routes upon which merchants traveled. The English crown's relative inactivity in regulating merchants' travel and pricing decisions stemmed from its relative debility in levying and collecting taxes. First, parliament had to approve new taxes and tax rates. Thus, any royal scheme to "herd" merchants onto official routes, the better to extract payments from them, would have required parliament to set tolls at rates that would maximize profits. But urban representatives in the House of Commons would have opposed such tariffs. Second, most local tolls were set by towns that had acquired their collection rights in exchange for an annual farm paid to the crown (Masschaele 2007, pp. 150-51). Centralizing control over the setting and collection of tolls would have been opposed by both the Commons and the towns.

Parliament's check on taxes, combined with chartered towns' traditional collection rights, meant that the legal authority to levy tolls in England was fragmented across many actors, in such a way as to enhance merchants' exit options: "if traders deemed a town's toll collectors too aggressive or too arbitrary, they [could] vote with their feet..." (Masschaele 2007, p. 174). Their ability to do so meant that English "toll rates were exceptionally low, ordinarily constituting less than one percent of the average price of a commodity" (p. 161). On the Ottoman caravan routes, in contrast, "the general rate was 5\%" (Bulut 2001, p. 52).

All told, English merchants - as compared to their Ottoman counterparts - faced fewer price controls, had greater freedom in choosing the routes on which to ship their merchandise, and paid lower tariffs. They were thus better positioned to seize new market opportunities.

\section{THE COSTS AND BENEFITS OF FRAGMENTATION}

Thus far, I have focused on one particular exit option - the ability of merchants to ship their merchandise on multiple politically independent routes. I have argued that this ability, combined with parliamentary 
representation for cities, enabled European merchants to conduct their business freer of tax and regulatory burdens than their counterparts elsewhere in Eurasia. Other exit options - such as merchants' ability to choose their home bases (Gelderblom 2013), peasants' ability to choose the watermill at which to grind their grain (van der Beek 2010), and scientists' ability to choose where to live (Jones 2003, pp. 123-24) were also important in enhancing the free flow of people, goods, and ideas in Europe.

But what is the evidence that the benefits of political fragmentation, in the form of better exit options for various actors, outweighed the costs, in the form of under-provision of public goods, over-taxation of commerce, and war? The literature offers many competing analyses and narratives, with no consensual verdict on the net benefits. While European fragmentation sometimes spurred capital investment, as in the case of watermills (van der Beek 2010), it also led to hold-up problems in the provision of public goods (Rosenthal 1992). While European fragmentation sometimes stimulated trade, as it did when the Italians pioneered a sea route to Bruges, it also led to the proliferation of internal tariffs (Epstein 2000). While some emperors strangled trade in a fashion unimaginable in fractured Europe (see Baechler 1975; Jones 2003; Rowe 2013, p. 311), other absolutist rulers (such as the Fatimids) pursued more trade-friendly policies. Absent a complete accounting of all relevant policies, how could one prove that, all things considered, a fragmented Europe imposed fewer burdens on trade than other Eurasian regions? ${ }^{3}$

\section{MEASURING ECONOMIC LIBERTY}

My strategy to assess the total burdens rulers imposed on trade is to examine inter-city growth correlations. The correlation between two cities' growth rates depends on human interactions between them and natural events that affect both. At one extreme, two distant cities might never trade, never fight, and never experience common natural shocks. The expected correlation in the growth rates of such isolated cities is zero. At the other extreme, two nearby cities might trade many germs, goods, and people and experience much the same natural shocks. The expected correlation in such connected cities' growth rates can be quite high.

The human interactions that potentially correlate two cities' growth rates fall into two mutually exclusive and collectively exhaustive categories:

\footnotetext{
${ }^{3}$ Vries (2015) reviews some of the competing views, which are especially divergent as regards whether China's emperor or Europe's squabbling princes better promoted trade.
} 
war and trade. Warfare correlates two cities' growth negatively if they fight one another, positively if they fight as allies. Trade is the residual category and includes intentional exchanges of goods and people, as well as unintentional exchanges of pathogens, with both possibly occurring through intermediary cities.

\section{Operational Measurement}

Not surprisingly, pairwise inter-city growth correlations decline with the distance between the paired cities (Hernando, Hernando, and Plastion 2013). For example, London's growth rate correlates strongly with English cities' growth rates, weakly with German cities' growth rates, and not at all with Japanese cities' growth rates (over the period 1200-1800 CE). This decay of inter-city growth correlations with distance suggests that any assessment of how sensitive a given city's growth was to urban growth elsewhere should weight its correlations with nearer cities more heavily.

Define the urban potential of city $\mathrm{j}$ in year $\mathrm{t}$ as the sum of all other cities' populations (in some defined region), each discounted by distance to city j. More formally, let $U P_{j t}=\sum_{i \neq j} \frac{p o p_{i t}}{D_{i j}}$, where pop $\mathrm{it}_{\mathrm{it}}$ is city i's population at time $t$ and $D_{i j}$ is the great circle distance between cities $\mathrm{i}$ and $\mathrm{j}{ }^{4}$

I assess how sensitive city j's growth was to growth in other cities by examining the correlation $\rho_{\mathrm{j}}$ between $\mathrm{j}$ 's population growth and $\mathrm{j}$ 's urban potential growth over a given period. Intuitively, $\rho_{j}$ should be high when city $\mathrm{j}$ grew in tandem with other cities, especially those nearer to it. Bosker, Buringh, and van Zanden (2013) considered a somewhat similar measure of urban interdependence. I discuss the technical differences between our approaches in the Online Appendix and flag some divergent substantive results at a few points in the text. ${ }^{5}$

\section{Construct Validity: Market Integration}

If two cities are integrated into a single market, then their commodity prices can differ by no more than the cost of arbitrage between them. Their prices should converge at any given time and move together over time.

\footnotetext{
${ }^{4}$ Now widely used, urban potential scores were originally proposed by Stewart (1947).

${ }^{5}$ The Online Appendix may be found at https://sites.stanford.edu/gwcox/data.
} 
If inter-city growth correlations measure how freely neighboring cities trade with one another, then high (resp., low) growth correlations should imply high (resp., low) co-movement in commodity prices. Consistent with these expectations, traditional measures of price co-movement, where available, agree with my measure of co-movement in city populations. For example, Roman Studer (2015) shows that overtime correlations in grain prices were much higher in eighteenth-century Europe than in eighteenth-century India. As will be seen, overtime correlations in city populations were also substantially higher in Europe than South Asia. As another example, Studer (2015) shows that price correlations in northwest Europe were higher than in central Europe, and the same pattern holds in terms of inter-city growth correlations.

\section{Construct Validity: Growth Clusters}

The validity of inter-city growth correlations as an indicator of economic liberty can be further validated by investigating clusters of growing cities. In each century, I identify all western cities that exceed the 90th percentile in both population growth and urban potential growth. There is no guarantee that such cities, which I call "seeds," will exist but in practice they always do in Western Europe 1200-1800 CE. If two or more seeds were within $100 \mathrm{~km}$ of each other, I grouped them and calculated their centroid. All non-seed cities lying within 1 degree of latitude and longitude of the seed centroid and experiencing above-median growth rates were dubbed "neighbors." The cluster containing the largest number of seeds plus neighbors was the "top cluster."

Consistent with the idea that clustered urban growth reveals inter-city trade, the top clusters in Western Europe consisted of the cities at the forefront of proto-industrial development in each century. For example, in 1200 the top cluster comprised Bruges, Brussels, Ghent and Liege in Belgium, along with Dunkerque and Saint-Omer in northern France (I have underlined the seeds). By 1300, this cluster had expanded to include Bruges, Brussels, Ghent and Leuven in Belgium, Arras, Dunkerque and Saint-Omer in northern France, and Dordrecht and Middelburg in the Netherlands. An equally large cluster of nine cities emerged in Tuscany. By 1400, the top cluster had moved north into the Netherlands, centering on Alkmaar, Amsterdam, Delft, Dordrecht, Gouda, Haarlem, Hertogenbosch, Leiden, Utrecht, and Zaandam. The top cluster remained in the Netherlands in 1500 and 1600. By 1700 two roughly equal clusters existed in the Netherlands and England. In 1800, the top cluster lay in the English midlands. 


\section{INTER-CITY GROWTH CORRELATIONS IN EURASIA: SOME INITIAL FINDINGS}

I now compare inter-city growth correlations for 1,033 Eurasian cities whose populations are documented at 100-year intervals over the period 600-1800 CE. The data, based mostly on Tertius Chandler (1987), are described in the Appendix. Following Ronald Findlay and Kevin O'Rourke (2009), I divided Eurasia into five cultural regions: Western Europe (556 cities), Eastern Europe (174 cities), the Islamic World (86 cities), East Asia (117 cities), and South Asia (100 cities). I focused on two periods: $600-1100$ and $1200-1800$. These periods are meaningful in European history, as the wave of parliaments and communes begins largely in the twelfth century.

I begin by running a series of bivariate regressions of Growth $_{j t}$ (the logarithmic growth rate of population) on UPGrowth $_{j t}$ (the logarithmic growth rate of urban potential). ${ }^{6}$ The results of these regressions, one for each region-period, are presented in Table 1; the Appendix provides summary statistics.

As can be seen, European cities' growth rates were negligibly correlated in the pre-parliamentary period $(600-1100 \mathrm{CE})$. The relatively isolated and autarkic cities of the early medieval period did not grow in tandem. After the great revival of trade, however, cities' growth rates were positively correlated (1200-1800 CE). Bosker, Buringh, and van Zanden (p. 1430) report a similar finding.

Table 1 shows that the most inter-connected urban growth arose in Western Europe after 1200, which was the only Eurasian region-period combining high political fragmentation and high parliamentary density. Eastern Europe, with some fragmentation and some parliaments after 1200, also shows significant inter-city growth correlations. While East Asia 1200-1800 CE (a period including China's second commercial revolution) also exhibits some inter-connected urban growth, it is weaker than in Europe. The other region-periods exhibit negative or insignificant correlations. The lack of correlation in the Islamic World 600-1100 CE conflicts with Bosker, Buringh, and van Zanden's findings, a point to which I return later.

Comparing London and Istanbul illustrates inter-city growth correlations more concretely. If one models the population of 50 English and 25 Anatolian cities over the period 1200-1800 CE using only city fixed effects

\footnotetext{
${ }^{6} \mathrm{I}$ used the spgen package in Stata, as well as an R program graciously provided by Darin Christensen, to compute the urban potential scores.
} 
TABLE 1

EURASIAN URBAN GROWTH, BY REGION AND PERIOD

\begin{tabular}{lccc}
\hline \hline Region & Period & Coefficient & t statistic \\
\hline Western Europe & $600-1100$ & 0.02 & 0.11 \\
Western Europe & $1200-1800$ & $1.42^{* * *}$ & 18.78 \\
Eastern Europe & $600-1100$ & 0.66 & 1.09 \\
Eastern Europe & $1200-1800$ & $0.96^{* * *}$ & 3.06 \\
North Africa and Mideast & $600-1100$ & -0.01 & -0.04 \\
North Africa and Mideast & $1200-1800$ & -0.32 & -1.09 \\
East Asia & $600-1100$ & $-1.18^{* *}$ & -2.13 \\
East Asia & $1200-1800$ & $0.27^{* *}$ & 2.04 \\
South Asia & $600-1100$ & -0.16 & -0.88 \\
South Asia & $1200-1800$ & $-0.44^{* *}$ & -2.50 \\
\hline
\end{tabular}

$*$ = Significant at the 10 percent level.

** = Significant at the 5 percent level.

$* * *=$ Significant at the 1 percent level.

The coefficient is from a bivariate regression of Growth $_{j t}$ on UPGrowth ${ }_{j t}$, pooling all observations in the given region and period.

Source: See the Appendix.

and the contemporaneous population of the metropolis, one finds that London's population significantly predicts other English cities' populations, but Istanbul's (or Constantinople's) population is statistically unrelated to urban populations elsewhere in Anatolia. Istanbul/Constantinople was a classic imperial capital, which grew large by commanding the resources it needed (cf. Boyar 2013; Bulut 2001). In contrast, London was a prototypical trading center, which grew via voluntary exchanges (cf. van Bavel et al. 2013).

Figure 1 plots the century-by-century correlation between Growth $_{j t}$ and UPGrowth ${ }_{j t}$ for cities in two of the five regions. As can be seen, inter-city growth correlations in the Islamic World and Western Europe were very similar in 600,800,1000, and 1100. Beginning in 1200, however, Europe exhibits noticeably more inter-connected urban growth, lapsing only in 1500 and 1600 (as I discuss in more detail later in the article).

Together, Table 1 and Figure 1 suggest a sea-change in need of explanation. Why were urban growth patterns similar across Eurasia in 600-1100 CE, only to diverge thereafter? Why did Western and Eastern Europe after 1200 exhibit by far the largest positive correlations between nearby cities' growth rates? Logically, inter-city growth correlations must have been driven by some combination of Nature, war, and trade. Thus, one must look to these factors to answer the questions just posed. 


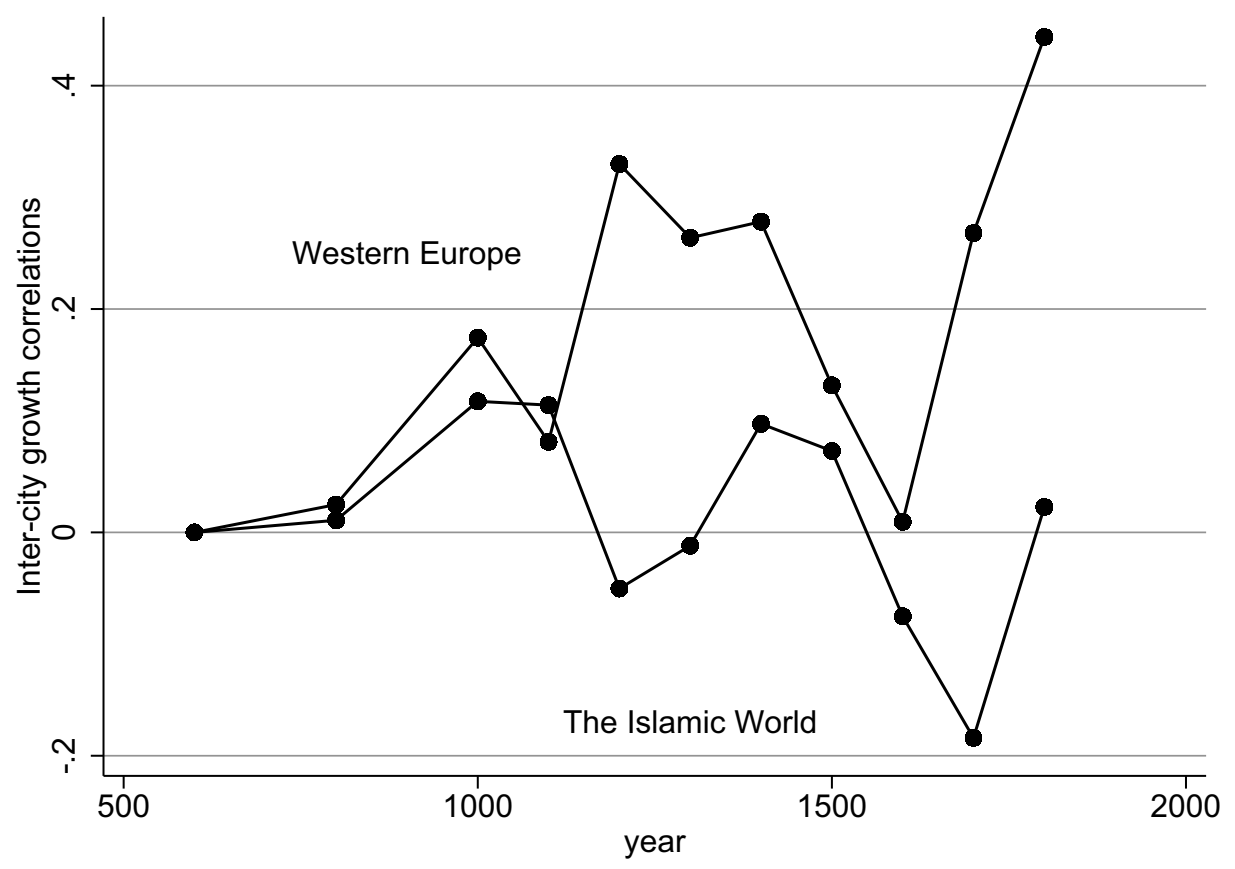

FIGURE 1

INTER-CITY GROWTH CORRELATIONS IN THE WESTERN CORE

Source: See the Appendix.

\section{INTER-CITY GROWTH CORRELATIONS: \\ A MORE CONTROLLED LOOK}

Table 2 examines growth correlations in the period 1200-1800 CE more carefully. The estimating model, given in equation (1), regresses each city's logarithmic growth rate on the logarithmic growth rate of its urban potential, while controlling for lagged population, city-specific fixed effects $\left(\alpha_{\mathrm{j}}\right)$, and a full set of region-specific century effects $\left(\theta_{\text {region(j)t }}\right.$, where region $(\mathrm{j})$ denotes the region containing city $\mathrm{j}$ ):

$$
\text { Growth }_{j t}=\alpha_{\mathrm{j}}+\theta_{\text {region(j)t }}+\beta \ln \left(\text { pop }_{j, t-\mathrm{l}}\right)+\gamma_{\text {region(j) }} \text { UPGrowth }_{j t}+\varepsilon_{\mathrm{jt}} .
$$

The coefficient $\gamma_{\text {region(i) }}$ indicates whether the cities in a given region tended to grow in tandem with their neighbors.

The errors (here and henceforward) are clustered at the modern country level. Modern country boundaries, albeit imperfectly, sort cities into groups that are linguistically and culturally similar, facilitating the 
TABLE 2

INTER-CITY GROWTH CORRELATIONS IN FIVE EURASIAN REGIONS

\begin{tabular}{lcccc}
\hline \hline & $\begin{array}{c}\text { Model 1 } \\
\text { (All Cities, }\end{array}$ & $\begin{array}{c}\text { Model 2 } \\
\text { (Big Cities, }\end{array}$ & $\begin{array}{c}\text { Model 3 } \\
\text { (All Cities, }\end{array}$ & $\begin{array}{c}\text { Model } 4 \\
\text { (All Cities, }\end{array}$ \\
Independent Variables & $1200-1800)$ & $1200-1800)$ & $1200-1800)$ & $1200-1500)$ \\
\hline ln(pop ${ }_{t-1}$ ) & $-0.39^{* * *}$ & $-0.34^{* * *}$ & $-0.41^{* * *}$ & $-0.62^{* * *}$ \\
& $(0.03)$ & $(0.04)$ & $(0.03)$ & $(0.05)$ \\
Western Europe: UPGrowth & $1.72^{* * *}$ & $2.23^{* *}$ & $0.91^{* *}$ & 0.77 \\
& $(0.44)$ & $(0.93)$ & $(0.46)$ & $(0.62)$ \\
Eastern Europe: UPGrowth & 0.85 & 1.01 & $-1.26^{*}$ & $-1.82^{*}$ \\
& $(0.85)$ & $(1.42)$ & $(0.67)$ & $(0.91)$ \\
North Africa and Mideast: & -0.34 & -0.44 & $-1.97^{* * *}$ & -0.58 \\
UPGrowth & $(0.26)$ & $(0.25)$ & $(0.56)$ & $(0.65)$ \\
East Asia: UPGrowth & 0.08 & 0.05 & $-1.67^{* * *}$ & $-1.58^{* * *}$ \\
& $(0.13)$ & $(0.16)$ & $(0.21)$ & $(0.15)$ \\
South Asia: UPGrowth & $-0.42^{* * *}$ & $-0.51^{* * *}$ & $-1.78^{* * *}$ & $-1.51^{* * *}$ \\
& $(0.06)$ & $(0.08)$ & $(0.30)$ & $(0.10)$ \\
City fixed effects? & & & & \\
Region-century fixed effects? & Yes & Yes & Yes & Yes \\
Gridcell-century fixed effects? & No & Yes & No & No \\
Number of observations & 4,559 & 1,610 & 4,559 & 2,017 \\
Number of cities & 928 & 298 & 928 & 701 \\
Errors clustered at country level; & 60 & 45 & 60 & 57 \\
number of countries = & & & & \\
$\mathrm{R}^{2}$ (within) & 0.28 & 0.25 & 0.43 & 0.51 \\
\hline - & & & &
\end{tabular}

* = Significant at the 10 percent level.

** = Significant at the 5 percent level.

*** = Significant at the 1 percent level.

Dependent variable $=$ logarithmic growth rate of population.

Source: See the Appendix.

propagation of ideational shocks. Clustering at either the gridcell level (as defined later) or the city level yields standard errors that preserve the main conclusions drawn later. ${ }^{?}$

The city fixed effects control for a wide range of natural characteristics such as seaside location, ruggedness of terrain, and elevation. Collectively, these time-invariant characteristics can be viewed as defining a given

\footnotetext{
${ }^{7}$ Clustering at the city level only makes sense if one believes that the spatial decay assumed in computing the urban potential scores adequately captures all relevant spillover and diffusion processes so that, controlling for growth in urban potential, inter-city growth rates are spatially uncorrelated. I discuss this matter further in the Online Appendix.
} 
city's "route substitutability" - how many different routes were available upon which the city's trade might have flowed, and how steeply transport costs increased as one moved from better to worse routes.

The region-specific century effects allow phenomena such as droughts, cold weather, or the Golden Horde to affect different regions differently. When these terms are not included, region-specific shocks due to weather and war affect inter-city growth correlations.

The main results (Model 1) show that substantively and statistically significant inter-city growth correlations existed in post-1200 Western Europe alone. Growth correlations were statistically insignificant in Eastern Europe, the Islamic World, and East Asia, and negative and significant in South Asia (discussed later). In the remainder of this section, I consider a series of doubts that might be raised about these initial findings.

\section{Urban Growth in Islam's Golden Age}

Bosker, Buringh, and van Zanden (p. 1430) report significant interdependence among Muslim cities in 800, 900, and 1000. Their finding seemingly conflicts with mine. However, when one adds region-specific century effects to their analyses, the coefficient estimates shrink by between 33 and 50 percent (depending on the century). Meanwhile, the standard errors increase substantially, leaving no statistically significant evidence that Muslim cities were interdependent (see the Online Appendix for details).

To illustrate why including region-specific century effects is important, consider Muslim cities during the eighth century. The Arab conquest of the Maghreb and Iberia during that century fostered urban growth in those areas, as soldiers and administrators flowed in. Once one nets out the region-wide tendency for all frontier cities to grow as a by-product of conquest, cities in Iberia and the Maghreb appear to have been only weakly inter-connected.

\section{Data Quality}

Is the contrast between Western Europe and the rest of Eurasia an artifact of there being more data for the west? To address this concern, Model 2 restricts the West European sample to cities whose populations exceeded 40,000 at some point between 800 and 1800 and recalculates the urban potential scores using only these qualifying cities. This ensures that the same cutoff is used throughout Eurasia. As can be seen, growth 
correlations among Europe's largest cities were comparable to those among European cities more generally.

Table 2's results could be due to larger errors in estimating nonwestern cities' populations. Such a premise is questionable, especially for big cities in stable empires. Even if measurement errors were larger outside Western Europe, this could not explain the findings. In Model 3 (discussed later), all regions except Western Europe show negative and significant correlations. Noisy data can only explain an attenuation toward zero.

\section{Endogenous Economic Growth}

Once cities start to grow at a high enough rate, it is possible that interconnected growth follows naturally, due to purely economic interactions. To explore this possibility, I first compared the Yangzi Delta, a highgrowth area of China, to the Netherlands, a high-growth area of Europe. As can be seen in the Online Appendix, cities in the Yangzi Delta did not exhibit inter-connected growth, whereas the Dutch cities did.

To identify areas of high growth more systematically, I divided Eurasia into 204 gridcells, each 5 degrees of latitude (roughly $550 \mathrm{~km}$ ) wide and 5 degrees of longitude (roughly $400 \mathrm{~km}$ ) tall. As a point of reference, gridcell number 149 contains a rectangle lying mostly in southern France and extending from Carcassone to Marseille on the southern border and from Bourges to Besançon on the northern border. I then reran Model 1 on a sample of Eurasian cities from high-growth gridcells (namely, all cells experiencing growth rates above the median for Western Europe). As shown in the Online Appendix, high-growth areas outside Western Europe showed no significant inter-urban growth correlations. Positive inter-city growth correlations did not automatically arise as soon as some threshold growth rate was passed.

\section{Other Robustness Checks}

Were the areas within which cities shared common natural shocks smaller than the five large regions thus far considered? To address this concern, I reran Model 1 with a full panel of gridcell-century indicators. These finer-grained area-year controls should better control the effects of Nature on inter-city growth correlations.

The results (Model 3) show that Western European cities' growth was positively and significantly associated with their neighbors' growth within each gridcell-century. Everywhere else in Eurasia, however, inter-city 
growth correlations were negative and significant. Among other things, these negative correlations reflect warfare between neighboring cities and coercive reallocations of assets. For example, new emperors sometimes founded new capital cities, which then extracted resources from their neighbors by command. ${ }^{8}$

I also explore whether the emergence of inter-connected urban growth in Western Europe could have been driven by war, rather than trade. In Western Europe, neighboring cities often traded with each other and, when wars broke out, allied with each other. Thus, both trade and war positively correlated their growth. When European wars pitted local cities against one another, mainly in the Hundred Years War, the Great Italian Wars, and the wars of religion, inter-city growth correlations declined substantially — as witnessed by the dip in Figure 1 in the years 1500 and 1600 .

To begin to parse the effects of war and trade, Model 4 restricts the sample to the period before Europe's military revolutions (1200-1500 $\mathrm{CE})$ and again controls for gridcell-century effects. Although inter-city growth correlations in Western Europe are not statistically greater than zero in this period, they are statistically greater than the correlations in every other Eurasian region. That is, the coefficient on UPGrowth in Western Europe is statistically significantly greater than the coefficient on UPGrowth in the other regions. There is no observable delay between the posited causes - the creation of local and national assemblies in a context of great political fragmentation - and the effects.

Finally, the results might reflect dynamic panel bias (Nickell 1981). To allay such a concern, I replicated Model 1's results using an ArrelanoBond estimator (see the Online Appendix).

\section{Summary}

I have shown that urban growth in post-1200 Western Europe was more inter-connected than it had been before and then it was in other Eurasian regions. These findings are consistent with the notion that European merchants, after the onset of self-governing cities and national parliaments, enjoyed greater economic liberty than their counterparts elsewhere. If representative institutions were the key factors enhancing

\footnotetext{
${ }^{8}$ When only region-century effects are controlled, common shocks at the gridcell-century level - due for example to weather and plague - positively correlate city growth rates. Once common shocks at the gridcell-century level are controlled, these positive contributions are removed and the contribution from fighting becomes more obvious. This likely explains why the region-specific UPGrowth coefficients in Model 3 are more negative than those in Model 1.
} 
the freedom of trade, however, then we should see differences within Europe, since institutions varied across both time and space.

\section{INTER-CITY GROWTH CORRELATIONS IN WESTERN EUROPE}

In this section, I exploit Bosker, Buringh, and van Zanden's dataset on city populations in the western core over the period 800-1800 CE. Crucially for my purposes, their widely used dataset provides comprehensive information on Europe's experience with representative institutions. Thus, one can gauge how the birth or demise of parliaments and city councils affected European cities' growth.

Focusing on Western Europe, I first regress the logarithmic growth rate of city j's population on the same regressors specified in equation (1), ${ }^{9}$ adding two new indicator variables, Commune ${ }_{j t}$ (equal to 1 if city $\mathrm{j}$ was self-governing in century $\mathrm{t}$ ) and Parliament $_{j t}$ (equal to 1 if city $\mathrm{j}$ was in a parliamentary realm in century $\mathrm{t}$ ). I also add a battery of time-varying controls from Bosker, Buringh, and van Zanden's dataset: whether and when each city had a bishop, an archbishop, a university, and a madrasas; and whether and when each city was a capital, was under Muslim control, or had been plundered in the previous century. This specification, similar to some run by Bosker, Buringh, and van Zanden, estimates the effects of institutional innovations using a difference-in-differences approach.

The results show that a city gaining communal status experienced a growth rate that was, on average, 10 percent higher thereafter (see Model 1 of Table 3). Cities whose realms gained a national parliament typically experienced growth rates that were higher by about 16 percent. These findings are qualitatively similar to those Bosker, Buringh, and van Zanden report in their Table 3 (p. 1434).

\section{Measuring the Strength of Parliaments}

In contrast to Bosker, Buringh, and van Zanden, Carles Boix (2015) relying on much the same data - concludes that parliaments were "causally irrelevant" to growth. The main reason for this disagreement has to do with how parliaments were coded. Bosker, Buringh, and van Zanden coded a dummy variable, equal to 1 if parliament sat at least once in the

\footnotetext{
${ }^{9}$ I follow Bosker, Buringh, and van Zanden in using co-religionist urban potential. However, all results hold also for a religion-blind measure of urban potential. I included Russian cities (from Bairoch, Batou, and Chevre 1988) when calculating the urban potential scores, to ensure that Eastern European did not have artificially lowered scores. The regions in this analysis are three: Western Europe, Eastern Europe, and Southern Europe.
} 
TABLE 3

EXPLAINING INTER-CITY GROWTH CORRELATIONS IN WESTERN EUROPE

\begin{tabular}{|c|c|c|c|}
\hline Independent Variables & $\begin{array}{c}\text { Model } 1 \\
\text { (Western Europe, } \\
1200-1800 \text { ) }\end{array}$ & $\begin{array}{c}\text { Model } 2 \\
\text { (Western Europe, } \\
1200-1800)\end{array}$ & $\begin{array}{c}\text { Model } 3 \\
\text { (Western Europe, } \\
1200-1500 \text { ) }\end{array}$ \\
\hline $\ln \left[p o p_{t-1}\right]$ & $\begin{array}{c}-0.62 * * * \\
(0.05)\end{array}$ & $\begin{array}{c}-0.62 * * * \\
(0.05)\end{array}$ & $\begin{array}{c}-0.89 * * * \\
(0.04)\end{array}$ \\
\hline UPGrowth & $\begin{array}{c}0.55^{* *} \\
(0.22)\end{array}$ & $\begin{array}{l}0.40^{*} \\
(0.21)\end{array}$ & $\begin{array}{l}-0.09 \\
(0.26)\end{array}$ \\
\hline Commune & $\begin{array}{c}0.10^{* *} \\
(0.04)\end{array}$ & $\begin{array}{r}0.10^{* *} \\
0(.03)\end{array}$ & $\begin{array}{c}0.03 \\
(0.10)\end{array}$ \\
\hline Parliament & $\begin{array}{c}0.16^{* *} \\
(0.06)\end{array}$ & $\begin{array}{l}0.09^{*} \\
(0.05)\end{array}$ & $\begin{array}{c}0.20^{* * *} \\
(0.05)\end{array}$ \\
\hline Parliament* UPGrowth & & $\begin{array}{l}0.22^{*} \\
(0.11)\end{array}$ & $\begin{array}{c}0.20^{* * *} \\
(0.07)\end{array}$ \\
\hline Battles & & & $\begin{array}{c}0.29 \\
(0.24)\end{array}$ \\
\hline City fixed effects? & Yes & Yes & Yes \\
\hline Region-specific century fixed effects? & Yes & Yes & Yes \\
\hline $\begin{array}{l}\text { Bosker, Buringh, and van Zanden's } \\
\text { other controls? }\end{array}$ & Yes & Yes & Yes \\
\hline Number of observations & 1,453 & 1,453 & 504 \\
\hline Number of cities & 419 & 419 & 196 \\
\hline $\begin{array}{l}\text { Errors clustered at the country level; } \\
\text { number of countries = }\end{array}$ & 18 & 18 & 15 \\
\hline $\mathrm{R}^{2}$ (within) & 0.41 & 0.42 & 0.57 \\
\hline
\end{tabular}

Dependent variable $=$ logarithmic growth rate of population

* = Significant at the 10 percent level.

** = Significant at the 5 percent level.

$* * *=$ Significant at the 1 percent level.

Dependent variable $=$ logarithmic growth rate of population.

Sources: All variables are from Bosker, Buringh, and van Zanden, "Baghdad to London," except Battles, which is from Bradbury, Medieval Warfare.

previous century. Boix (p. 219) used a continuous variable, the "fraction of years with parliamentary meetings in a given century." This difference in coding turns out to be the key explanation for the difference between Boix's results and those of Bosker, Buringh, and van Zanden Thus, it is important to explain why I prefer Bosker, Buringh, and van Zanden's variable.

Both Boix and Bosker, Buringh, and van Zanden seek to assess the institutional strength of parliament. A sensible ordinal measure, similar 
to one used by David Stasavage (2010, pp. 630-31), ranks parliaments as follows:

(1) Parliament suspended (or never existed).

(2) Parliament meets but controls neither taxing nor spending.

(3) Parliament meets and controls taxing, but not spending.

(4) Parliament meets and controls both taxing and spending.

As no parliament lacking control over taxes nonetheless controlled spending, these four categories are exhaustive.

Bosker, Buringh, and van Zanden's dummy variable distinguishes suspended or non-existent parliaments (level 1) from the rest (levels 2-4). The logic of Boix's "fraction of years" variable is that more powerful assemblies should have met more often. The problem is that many parliamentary cities experienced no change in parliamentary strength (as measured by the four-point scale earlier). For such cities, Boix's "fraction of years" variable cannot reflect parliamentary strength, since strength was time-invariant and thus absorbed in the unit fixed effect. Variations in the frequency of parliamentary sittings probably just reflected variations in warfare, since parliaments were called into session when their nations faced threats (Stasavage 2016, p. 18). Thus, if one wants to test the institutionalist thesis, one should use Bosker, Buringh, and van Zanden's variable, not Boix's.

It is possible that economic development (proxied by urban population growth) led to the formation of parliaments, rather than parliaments promoting economic growth. This is what Scott Abramson and Boix (2014) and Boix (2015), among others, argue. Perhaps the most compelling response, articulated by Stasavage (2016), runs as follows. Circa $1000 \mathrm{CE}$, Europe was likely poorer than the Byzantine Empire, the Abassid Caliphate, and especially the Chinese Empire. Yet, only Europe developed communes and parliaments over the next few hundred years. Thus, economic development per se did not promote parliamentarism.

\section{THE MEDIATING EFFECTS OF PARLIAMENTS}

For my purposes, it is more important to examine how representative institutions facilitated economic liberty, thereby increasing inter-city growth correlations, than to examine their direct effects on growth. To explore this issue, Model 2 adds an interaction term, $U_{P G r o w t h}{ }_{j t}^{*}$ Parliament $_{j t}$, to the analysis. 
The main effects of parliaments and communes, as well as the effects of the control variables, remain similar to those found in Model 1. The coefficient on UPGrowth ${ }_{j t}^{*}$ Parliament $_{j t}$ indicates that cities increased their sensitivity to nearby urban growth by about 50 percent, when their realms became parliamentary.

Did the introduction of parliaments coincide with more warfare, which then affected growth correlations? To address this concern, I control for each city's exposure to warfare (in Model 3). Using the list of European conflicts provided by Bradbury (2004), I calculated the distance $d_{k j}$ of each battle $\mathrm{k}$ from each city $\mathrm{j}$. I then calculated the distanceweighted number of battles witnessed by each city $j$ in each century $t$ as Battles $_{j t}=\sum_{k \in B_{t}} \frac{1}{d_{k j}}$, where $B_{t}$ is the set of battles occurring in century t.

The analysis is restricted to the period before Europe's military revolutions (1200-1500 CE). As can be seen, European cities in this period were unresponsive to growth in neighboring cities, if their realms had not yet become parliamentary. This corroborates the finding in Table 1 that western cities were no different than their Eurasian counterparts prior to 1200 . Once a European city's realm became parliamentary, however, that city became significantly more responsive to nearby urban growth (as indicated by the significant coefficient on the interaction term, UPGrowth ${ }_{j t}^{*}$ Parliament $_{j t}$. . Meanwhile, the main effect of introducing a parliament remains positive and significant; cities grew more quickly after their realm became parliamentary. As for warfare, cities closer to more fighting tended to grow faster, consistent with the "safe harbor" thesis explored by Mark Dincecco and Massimiliano Onorato (2015).

\section{Spillovers}

According to my account, princely cities near newly parliamentary cities should themselves have become more sensitive to urban growth in their environs. To investigate this possibility, I calculate each city's parliamentary urban potential: the sum of populations in parliamentary cities, each discounted by its distance from the focal city. Focusing just on non-parliamentary cities in Western Europe 1200-1500 CE, I first regressed their population growth on the growth of their ordinary urban potential and the usual battery of controls. The results (reported in the Online Appendix) show a negative and insignificant effect of UPGrowth: princely cities in the west were no more responsive to general urban growth than were other Eurasian cities in this period. 
I then replaced UPGrowth with PUPGrowth, the growth rate of each city's parliamentary urban potential. The results (again in the Online Appendix) show that princely cities were highly responsive to growth in nearby parliamentary cities. This is consistent with the idea that such cities matched the parliamentary cities' policies, in order to participate in the growing market economy. In other words, political reforms had important spillover effects for economic liberty.

\section{Spurious Correlation}

Did political fragmentation give merchants exit options, which they leveraged to extract both trade-friendly policies and parliamentary representation? If so, then the key factor would be merchants' de facto power (due to their exit options). Their de jure power (due to representative institutions) might have been only spuriously correlated with improved trade and the higher inter-city growth correlations that it fostered.

Note, however, that my analyses hold fixed the average exit options merchants enjoyed in any given area and time, by including area-specific century effects. Thus, the effects of parliaments and communes uncovered in my analyses reflect the de jure powers they wielded, controlling for their de facto power.

It makes sense, moreover, that representative institutions would help merchants protect their interests, above and beyond any leverage they had due to exit options. In order to expand their commercial enterprises, merchants had to invest in easily confiscated buildings and machines, and to ship their merchandise on roads and waterways where it could easily be taxed. If they relied solely on exit threats - e.g., that they would relocate in response to princely predation - then it would only be a matter of time until a large enough liquidity shock convinced a desperate prince to confiscate. At that point, urban elites would either have to bear the costs of relocation or endure the depredation. Thus, merchants sought greater security, in the form of voting rights enabling them to block the prince from levying confiscatory tariff surcharges in the first place, rather than being limited to retaliating after the fact.

\section{WEAK AND STRONG PARLIAMENTS}

The ability of medieval parliaments to keep tariffs low depended on their ability to approve or deny the ruler's tax requests. Some parliaments, such as those in England and the Netherlands, successfully defended their tax power. Others, most notably the Estates General of France, originally 
TABLE 4

INTER-CITY GROWTH CORRELATIONS AND PARLIAMENT'S TAX POWER

\begin{tabular}{lccc}
\hline \hline Country & Before Parliament & $\begin{array}{c}\text { When Parliament } \\
\text { Controlled Taxes }\end{array}$ & $\begin{array}{c}\text { When Parliament Did } \\
\text { Not Control Taxes }\end{array}$ \\
\hline France & 0.10 & $0.33^{* * *}$ & 0.07 \\
& $(54$ city-years, & $(62$ city-years, & $(175$ city-years, \\
& $800-1200)$ & $1300-1400)$ & $1500-1800)$ \\
Poland & Insufficient data & Never & -0.11 \\
& & & $(16$ city-years, \\
& & & $1400-1600)$ \\
England & 0.12 & $0.64 * * *$ & Never \\
& $(13$ city-years, & $(79$ city-years, & \\
Netherlands & $800-1300)$ & $1400-1800)$ & Never \\
& -0.06 & $0.31 * * *$ & \\
& $(9$ city-years, & $(73$ city-years, & $1500-1800)$ \\
\hline
\end{tabular}

$*=$ Significant at the 10 percent level.

$* *$ Significant at the 5 percent level.

$* * *$ Significant at the 1 percent level.

The cell entries give the bivariate correlation between Growth and UPGrowth, pooling all observations from the given country and period.

Sources: All variables are from Bosker, Buringh, and van Zanden, "Baghdad to London."

had the power to block new taxes but later lost it, whereas the Polish Diet always lacked any corporate power to approve new taxes (since unanimous consent was required). In both France and Poland, urban representatives should have had difficulty influencing crown policies: The French could not block their monarch's reach for new taxes, while the Polish could not materially assist their king, should opposition from any of the great landed magnates arise.

Table 4 provides evidence that parliament's tax power mattered. In particular, the bivariate correlation between population growth and urban potential growth was positive and significant only when parliament controlled taxes.

France offers the most striking pattern. Before the Estates General began meeting, the average inter-city growth correlation (within the modern borders of France) was small and insignificant. In the two centuries during which the Estates controlled taxes, the correlation tripled in size and became statistically significant. After the Estates lost their ability to block taxes, the correlation again became small and insignificant.

The other cases exhibit a similar pattern. Growth correlations were low when there was no parliament according to Bosker, Buringh, and van Zanden's coding (the United Kingdom prior to 1400 and the 
Netherlands prior to 1500) or a weak one (Poland), but they were high under strong parliaments (the later years for the United Kingdom and the Netherlands). ${ }^{10}$ To show that this pattern remains in a more controlled analysis, I pooled the data from the four countries and ran the following regression:

$$
\begin{gathered}
\text { Growth }_{j t}=\alpha_{\mathrm{j}}+\beta_{1} \text { Meangrowth }_{j t}+\beta_{2} \text { Weak }_{j t}+\beta_{3} \text { Strong }_{j t} \\
+\gamma_{0} \text { UPGrowth }_{j t}+\gamma_{1} \text { Weak }_{j t} \cdot \text { UPGrowth }_{j t}+\gamma_{2} \text { Strong }_{j t} \cdot \text { UPGrowth }_{j t}+\varepsilon_{\mathrm{jt}}
\end{gathered}
$$

Here, $\alpha_{\mathrm{j}}$ is a city fixed effect, Meangrowth ${ }_{j t}$ is the mean growth experienced in city j's country in century $\mathrm{t}$, Weak $_{j t}=1$ if there is a fiscally weak parliament, and Strong $_{j t}=1$ if there is a fiscally strong parliament.

The most important results (detailed in the Online Appendix) were that cities were negatively affected by nearby urban growth in their nonparliamentary eras; insignificantly more inter-connected during their weak-parliamentary eras; and significantly more inter-connected during their strong-parliamentary eras. In terms of absolute levels, cities were positively and significantly inter-connected only during strong-parliamentary eras.

Qualitatively similar results hold if one runs separate countryby-country regressions (although they are statistically weak for the Netherlands). Moreover, similar results hold if one replaces Meangrowth with a battery of country-specific century effects and controls for lagged population.

The results suggest that parliaments promoted freer trade and hence more inter-connected urban growth. Somewhat in contrast, Bosker, Buringh, and van Zanden found a stronger mediating effect for communes than for parliaments. However, when one adds region-specific century effects to their specification, their results become largely consistent with those I report in Table 3 (see the Online Appendix for details).

\section{THE GIFTS OF DISCORDIA AND EUROPEAN DIVERGENCE}

As do Jean Baechler (1975), Eric Jones (2003), and others, I view the collapse of central authority after the fall of the Roman and Carolingian Empires as the root cause of European divergence. Imperial collapse led to a wave of local self-defense and state-building efforts. Later, using tools provided by the legal revolution of the twelfth century (Berman 1983), Europe's de facto political fragmentation achieved de jure

\footnotetext{
${ }^{10}$ If one codes England as having a parliament beginning in 1300, the results remain the same.
} 
recognition-spawning city-states, communes, liberties, charters and parliaments. The European landscape was covered by hundreds of small polities, most of them bottom-up creations rather than top-down impositions (Spruyt 1994; Blockmans 1997; Abramson forthcoming).

The spread of parliaments and communes interacted with Europe's continuing fragmentation to free merchants from central regulation and taxation. Economic liberty sparked a wave of innovations lowering transaction costs (Greif 2006; de Moor 2008). Economic liberty also spread pathogens, ideas, laborers, and goods, which powerfully and positively correlated city growth rates. My analyses document a relatively sudden emergence of inter-connected urban growth in Western Europe and show that it was driven mainly by trade (as both Nature and war were controlled). ${ }^{11}$ In this section, I consider two questions that my account raises.

\section{Why Not Sooner?}

If Europe's political fragmentation and representative institutions fostered economic liberty, then why did per capita incomes in Europe not begin to diverge sooner? One response is that Malthusian dynamics should have limited European divergence. Even with marginally better economic liberty compounding over many years, populations could still grow much faster than productivity, forcing per capita incomes down by the remorseless logic of Malthus' iron law of wages (Voigtländer and Voth 2012). Given Europe's relative under-development in 1200, it is perhaps not surprising that Western European incomes do not begin to diverge until 1500 (Broadberry 2013).

Still, Europe's divergence becomes dramatic only with the first Industrial Revolution. Why did the trio of political fragmentation, representative institutions and economic liberty not spark faster growth than it did? By way of answer, I would stress that each element in the trio could harm economic growth, as well as helping it.

Political fragmentation led to wars that killed many people and destroyed much property (Rosenthal and Wong 2011). ${ }^{12}$ Moreover, fragmentation could take not just a beneficial, inter-route form, but also a

\footnotetext{
${ }^{11}$ Additional evidence of post-1200 Europe's relatively free trade is that cities in this regionperiod complied better with Zipf's Law than any other region-period. To document this is beyond the scope of the present article. Dittmar 2011 provides some relevant analysis.

${ }^{12}$ That said, warfare could boost urban growth, as cities became "safe harbors" (Dincecco and Onorato 2015). Moreover, because medieval wars reduced the population faster than they destroyed the capital stock, they boosted per capita incomes among the survivors (Voigtländer and Voth 2012).
} 
harmful, intra-route form - with the latter spawning serious free rider and common pool problems (Epstein 2000; Rosenthal and Wong 2011, ch. 6).

Meanwhile, Europe's assemblies had mixed potential for growth. They represented mainly small elite groups, who were just as prone to restrict trade as were princes, when they could get away with it. So, empowering assemblies sometimes simply replaced rent-extracting monarchs with rent-extracting oligarchs (Epstein 2000; Stasavage 2014). Moreover, when assemblies internally decentralized fiscal power, they created a common pool problem that led to fiscal imprudence (Hallerberg, Strauch, and von Hagen 2010). Both problems - rent extraction by closed oligarchies and over-fishing of the fiscal common pool-persisted for centuries and could substantially worsen economic performance.

Finally, David Newbery and Joseph Stiglitz's (1984) seminal article showed that increasing trade, without improving insurance, can lower welfare. To illustrate, suppose trade is initially negligible. Farmers who harvest meager crops due to locally bad weather can accordingly charge higher prices. Once regional trade in agricultural products commences, however, farmers suffering local shocks will simply lose income. The market, in other words, may increase both the mean and variance of their income. For present purposes, the point is simply that the net benefits of freer trade would initially have been ambiguous in medieval Europe, given how poorly developed capital markets were. Indeed, Avner Greif, Murat Iyigun, and Diego Sasson (2013) argue that elite worries about the social disorder that market integration could bring strongly impeded development throughout Eurasia.

In the long term, the dark sides of political fragmentation, representative institutions and economic liberty could be mitigated. Because Europeans fought so many wars, they eventually developed mechanisms - such as establishing clear borders - that reduced their incidence. Because Europeans experienced so many oligarchic or imprudent assemblies, they eventually developed mechanisms to deal with these problems. In Great Britain, for example, the Municipal Corporations Act 1835 ended traditional urban oligarchies by extending suffrage rights to all ratepayers, obliging the reformed boroughs to publish their financial accounts, and exposing them to audit. Because Europeans traded so much, they eventually developed vibrant insurance markets, both private and social, thereby enabling them to more fully realize the wealth-creating potential of trade. In Britain, for example, Greif and Iyigun (2012a, 2012b) highlight the importance of the Old Poor Law.

In sum, Europeans had the opportunities to perfect multipolar balanceof-power politics, to improve how representative institutions operated, 
and to develop capital markets - and they eventually seized those opportunities. Meanwhile, in the rest of the world, large empires created a different international politics; there was no possibility of perfecting representative institutions, since none existed; and state regulation of trade reduced the demand for better insurance.

\section{Why Not Elsewhere?}

If European trade fostered inter-connected urban growth, then why did trade elsewhere not do so? The answer is that increasing trade in other regions did lead to more inter-connected urban growth. The effects were just not as sustained or dramatic as in Europe.

To illustrate, consider China. The Middle Kingdom experienced relatively high commercial activity under the Song and Yuan dynasties, and again during the "second commercial revolution" beginning in the midsixteenth century. In between, however, lay the Ming dynasty, whose founder commenced his reign in 1368 by systematically destroying the lower Yangzi's mercantile lineages and instituting a ban on maritime travel that "severely constricted the trade along the coast and with South East Asia..." (Rowe 2013, p. 311). Meanwhile, merchants traveling within the empire "were required to stay and register at semi-governmental hostels, whose records were turned in monthly to the local official for inspection" (p. 311). The rest of the economy was "minutely regulated." While China generally had low transit taxes (Rosenthal and Wong, p. 174), the overall Ming reduction in trade freedom - with trading bans, travel restrictions, and continuing price controls - was profound.

As one would expect from this account, the century-by-century correlation between population growth and urban potential growth is lowest after the Ming rulers come to power (1400) and highest after the onset of the second commercial revolution. Even during China's second commercial revolution, however, inter-city growth correlations were less than half the level observed in Western Europe. This resonates with Wolfgang Keller, Carol Shiue, and Xin Wang (2015) finding, based on co-movements in interest rates, that eighteenth-century England's capital market was much better integrated than even the Yangzi Delta's.

\section{CONCLUSION}

Beginning circa 1500, the economies of northwest Europe diverged from their Eurasian competitors (Broadberry 2013, p. 10). Beginning in the late eighteenth century, with Great Britain leading the way, 
these economies embarked on a path of industrialization and "modern" economic growth. They thereby broke a pattern —of nearly zero longterm growth in per capita income - which they had shared with the rest of the world throughout recorded history.

Explaining this great divergence of European economies from the rest of the world has been a central goal in the social sciences since the nineteenth century. ${ }^{13}$ One line of thinking argues that Europe's unique political innovations - self-governing cities and national parliaments-limited princely predation, thereby improving the security of property rights and fostering Smithian growth (e.g., North 1981; North and Weingast 1989; De Long and Shleifer 1993; Acemoglu et al. 2005). Complementing these property-centered accounts, I argue that political fragmentation and representative institutions jointly determined the tariffs and regulations rulers could impose on trade and, hence, how inter-connected urban growth could become. Thus, within Eurasia I expect the highest inter-city growth correlations to arise in its most fragmented and parliamentary region, Western Europe. Within Western Europe, I expect the highest correlations in the most fragmented and parliamentary sub-regions.

To empirically explore these predictions, I introduce a distanceweighted measure of inter-city growth correlations. This measure correlates with traditional measures of market integration based on co-movements in prices, but also picks up deeper forms of economic integration, such as cooperation in specialized production chains. Using this new measure, I show that different networks of trading cities in Eurasia experienced quite different inter-city growth correlations. Correlations were everywhere negative or insignificant before 1200 and thereafter became consistently positive and significant only in Western Europe, the most fragmented and parliamentary of all the Old World's regions. Within Western Europe, inter-city growth correlations were particularly strong on politically fragmented coasts where fiscally strong parliaments survived.

Although Europe began to diverge in terms of economic liberty as soon as the wave of communes and parliaments washed over the continent, it was three centuries before greater liberty generated a detectable advantage in per capita income and another three centuries before this advantage began dramatically to widen. The net benefits of economic liberty accrued slowly for many reasons, including: (1) endemic warfare; (2) monarchs' efforts to suppress representative institutions, as soon as they could; (3) oligarchs' efforts to use representative institutions to suppress

\footnotetext{
${ }^{13}$ Just a few of the recent books on this topic include Pomeranz (2001), Jones (2003), Rosenthal and Wong (2011), Fukuyama (2011), Vries (2015,) and Studer (2015).
} 
rather than promote competition; and (4) the immiserating features of markets themselves in a time before either private or social insurance was readily available. In the long term, Europeans devised ways to mitigate these and other problems afflicting liberal states and market societies. As they did so, their relative advantage over their "natural state" competitors became overwhelming.

\section{Appendix}

I rely on two main datasets for the analyses in this article. One, compiled by Bosker, Buringh, and van Zanden (2013), is used in all analyses of Western Europe (Tables 3 and 4). The other, compiled by Andrea Biguzzi, is used in all pan-Eurasian analyses (Tables 1 and 2, Figure 1). The datasets (in Stata format), analytical files and the Online Appendix can be found at https://sites.stanford.edu/gwcox/data (see also Cox 2017).

I downloaded the pan-Eurasian data on 19 November 2015 from the Dr. Andrea Biguzzi's site: http://www.worldcitypop.com. In the first period, the dataset provides observations for the years $600,800,1000$, and 1100 . In the latter period, the dataset provides one observation per century (I discarded 1750). Most of Biguzzi's data come from Chandler (1987), a compendium with population data for all cities "which at any time from 800 to 1800 reached a population of 40,000 for Asia or 20,000 for the other continents." Meredith Reba, Femke Reitsma, and Karen C. Seto (2016) provide an extensive recent review of the quality of Chandler's data.

For Western Europe and the Islamic World, Biguzzi's data largely agrees with the data compiled by Bosker, Buringh, and van Zanden The correlation between the population figures they provide is 0.98 . That said, I prefer to use Bosker, Buringh, and van Zanden's data for all western analyses, since they provide more extensive documentation.

Appendix Table 1 provides summary statistics from the pan-Eurasian dataset.

I added what Findlay and O'Rourke call Central Asia to the Eastern European region (for all analyses). My results are not affected if instead Central Asia is excluded from the analysis. I excluded Southeast Asia from the analyses, but the results are similar if instead it is pooled with either East or South Asia.

For present purposes, the most serious worry in using Biguzzi's dataset concerns the differing sampling frames used in different parts of Eurasia. To deal with this issue, I first imposed the same sampling frame on all regions, by focusing just on the "big cities" (defined as those exceeding 40,000 residents at some point between 600 and $1800 \mathrm{CE}$ ). I then recalculated the urban potentials for Europe based just on the big cities - call this the big-city urban potential - and reran the analysis (see Model 2, Table 2). This solution - comparing big cities across regions - should work if (a) big cities were representative of all cities in terms of how responsive they were to nearby urban growth; and (b) big-city urban potential correlates highly with all-city urban potential.

Within the western core, one can use Bosker, Buringh, and van Zanden's dataset to calculate both all-city and big-city urban potentials. For Europe's big cities, the correlation between their all-city and big-city urban potentials was 0.99 . This suggests one can use big-city urban potential as a proxy for all-city urban potential in those areas where the latter is unavailable (South and East Asia). 
APPENDIX TABLE 1

\begin{tabular}{lcccc}
\hline \hline Region & Period & $\begin{array}{c}\text { Mean } \\
\text { Population }\end{array}$ & $\begin{array}{c}\text { Mean Growth } \\
\text { of Population }\end{array}$ & $\begin{array}{c}\text { Mean Growth } \\
\text { of Urban } \\
\text { Potential }\end{array}$ \\
\hline Western Europe & $600-1100$ & 17,608 & 0.11 & 0.10 \\
Western Europe & $1200-1800$ & 15,874 & 0.11 & 0.19 \\
Eastern Europe & $600-1100$ & 25,793 & 0.16 & 0.07 \\
Eastern Europe & $1200-1800$ & 17,634 & 0.17 & 0.15 \\
North Africa and Mideast & $600-1100$ & 71,281 & -0.03 & 0.06 \\
North Africa and Mideast & $1200-1800$ & 54,040 & -0.01 & 0.10 \\
East Asia & $600-1100$ & 105,461 & -0.00 & 0.09 \\
East Asia & $1200-1800$ & 100,213 & 0.05 & 0.13 \\
South Asia & $600-1100$ & 60,207 & -0.03 & 0.07 \\
South Asia & $1200-1800$ & 60,100 & -0.02 & 0.13 \\
\hline
\end{tabular}

To explore the validity of assumption (a), I again used Bosker, Buringh, and van

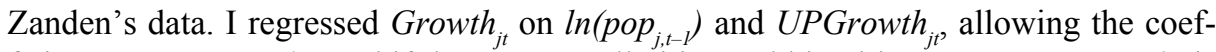

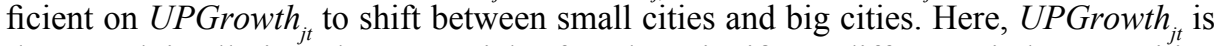
the growth in all-city urban potential. I found no significant difference in how sensitive big and small cities were to nearby urban growth. Thus, big cities were representative of all cities in terms of their sensitivity to nearby urban growth, at least in the western core.

Finally, I replicated the results for Western Europe from Model 2, Table 2, using Bosker, Buringh, and van Zanden's dataset. Thus, the results for Europe are not due to some peculiarity in how Biguzzi covered that region.

Once the same sampling frame is imposed, the mean population of the sampled cities in the various regions becomes more similar. For example, the mean population of the Western European cities entering the analysis in Model 2 (Table 2) is 46,508, not far short of the means in the Islamic World $(56,022)$ and South Asia $(60,100)$.

\section{REFERENCES}

Abramson, Scott F. "The Economic Origins of the Territorial State." International Organization forthcoming.

Abramson, Scott F., and Carles Boix. "The Roots of the Industrial Revolution: Political Institutions or (Socially Embedded) Know-How?" Unpublished Typescript. Princeton: Princeton University, 2014.

Abu-Lughod, Janet. Before European Hegemony. Oxford: Oxford University Press, 1989.

Acemoglu, Daron, Simon Johnson, and James Robinson. "Institutions as a Fundamental Cause of Long-run Growth." In Handbook of Economic Growth, Volume IA, ed. Philippe Aghion and Steven N. Durlauf. Amsterdam: Elsevier, 2005.

Baechler, Jean. The Origins of Capitalism. Translated by Barry Cooper. Oxford: Basil Blackwell, 1975.

Bairoch, Paul, Jean Batou, and Pierre Chevre. La Population des Villes Européennes, 800-1850. Geneva: Droz, 1988. 
Bates, Robert, and Da-Hsiang Donald Lien. “A Note on Taxation, Development, and Representative Government." Politics \& Society 14, no. 1 (1985): 53-70.

Berman, Harold. Law and Revolution: The Formation of the Western Legal Tradition. Cambridge, MA: Harvard University Press, 1983.

Blockmans, Wim. "Representation (Since the Thirteenth Century)." In The New Cambridge Medieval History, edited by Christopher Allmand, 29-64. Cambridge: Cambridge University Press, 1997.

Boix, Carles. Political Order and Inequality. Cambridge: Cambridge University Press, 2015.

Bosker, Maarten, Eltjo Buringh, and Jan Luiten van Zanden. "From Baghdad to London: Unraveling Urban Development in Europe, the Middle East, and North Africa, 800-1800." Review of Economics and Statistics 95, no. 4 (2013): 1418-37.

Boyar, Ebru. "The Ottoman City: 1500-1800." In The Oxford Handbook of Cities in World History, edited by Peter Clark, 275-91. Oxford: Oxford University Press, 2013.

Bradbury, Jim. The Routledge Companion to Medieval Warfare. New York: Routledge, 2004.

Broadberry, Stephen. "Accounting for the Great Divergence." Economic History Working Paper No. 184/2013, London School of Economics and Political Science, London, UK, 2013.

Bulut, Mehmet. Ottoman-Dutch Economic Relations in the Early Modern Period, 1571-1699. Hilversum: Verloren, 2001.

Chandler, Tertius. Four Thousand Years of Urban Growth: An Historical Census. Lewiston, NY: St. David's University Press, 1987.

Coffman, D'Maris, Adrian Leonard, and Larry Neal, eds. Questioning Credible Commitment: Perspectives on the Rise of Financial Capitalism. Cambridge: Cambridge University Press, 2013.

Cox, Gary W. Marketing Sovereign Promises. New York: Cambridge University Press, 2016.

_. "Political Institutions, Economic Liberty and the Great Divergence [Data set]". Inter-university Consortium for Political and Social Research [distributor], 2017. Available at https://doi.org/10.3886/E100636V1.

De Long, J. Bradford, and Andrei Shleifer. "Princes and Merchants: European City Growth before the Industrial Revolution." Journal of Law and Economics 36, no. 2 (1993): 671-702.

De Moor, Tine. "The Silent Revolution: A New Perspective on the Emergence of Commons, Guilds and Other Forms of Corporate Collective Action in Western Europe.” International Review of Social History 53, no. S16 (2008): 179-212.

Dincecco, Mark, and Massimiliano Onorato. "Military Conflict and the Rise of Urban Europe." Journal of Economic Growth 21, no. 3 (2015): 259-82.

Dittmar, Jeremiah. "Cities, Markets and Growth: The Emergence of Zipf's Law." Unpublished Typescript, LSE, 2011.

Epstein, Stephen R. Freedom and Growth: The Rise of States and Markets in Europe, 1300-1750. London: Routledge, 2000.

Findlay, Ronald, and Kevin O'Rourke. Power and Plenty: Trade, War, and the World Economy in the Second Millennium. Princeton: Princeton University Press, 2009.

Fukuyama, Frank. The Origins of Political Order. London, UK: Profile Books, 2011. 
Gelderblom, Oscar. Cities of Commerce: The Institutional Foundations of International Trade in the Low Countries, 1250-1650. Princeton: Princeton University Press, 2013.

Gennaioli, Nicola, and Hans-Joachim Voth. "State Capacity and Military Conflict." Review of Economic Studies 82, no. 4 (2011): 1409-48.

Grief, Avner. Institutions and the Path to the Modern Economy: Lessons from Medieval Trade. Cambridge: Cambridge University Press, 2006.

Greif, Avner, and Murat Iyigun. "Social Institutions, Violence \& Discoveries: Quantifying the Role of the Old Poor Law." Stanford University, Mimeo. 2012a.

Greif, Avner, and Murat Iyigun. "Social Organizations, Risk-Sharing Institutions and Economic Development." In Institutions and Comparative Economic Development, edited by Masahiko Aoki, Timur Kuran, and Gérard Roland, 48-63. London: Palgrave Macmillan, 2012b.

Greif, Avner, Murat Iyigun, and Diego Sasson. "Social Institutions and Economic Growth: Why England Rather Than China Became the First Modern Economy." Working Paper No. 465, Stanford Center for International Development, Stanford, CA, 2013.

Hallerberg, Mark, Rolf Strauch, and Jürgen von Hagen. Fiscal Governance in Europe. Cambridge: Cambridge University Press, 2010.

Harvey, Barbara. "Review of Royal Regulation of Loans and Sales in Medieval England." English Historical Review 120, no. 487 (2005): 766-68.

Hernando, A., R. Hernando, and A. Plastino. "Space-Time Correlations in Urban Sprawl." Interface 11, no. 91 (2013): 1-6.

Hirschman, Albert O. Exit, Voice and Loyalty. Cambridge, MA: Harvard University Press, 1970.

Jones, Eric. The European Miracle: Environments, Economies and Geopolitics in the History of Europe and Asia, 3rd edition. Cambridge: Cambridge University Press, 2003.

Keller, Wolfgang, Carol Shiue, and Xin Wang. "Capital Markets in China and Britain, $18^{\text {th }}$ and $19^{\text {th }}$ Century: Evidence from Grain Prices." NBER Working Paper No. 21349, Cambridge MA, 2015.

Landes, David S. The Wealth and Poverty of Nations. New York: W. W. Norton, 1999. Lopez, Robert S. The Rise of Europe. New York: M. Evans and Co., 1966.

Masschaele, James. "Toll and Trade in Medieval England." In Later Medieval Europe, Volume 1: Money, Markets and Trade in Late Medieval Europe: Essays in Honour of John H. A. Munro, edited by Lawrin Armstrong, Ivana Elbl, and Martin M. Elbl. Boston, MA: Brill Academic Publishers, 2007.

Newbery, David, and Joseph Stiglitz. "Pareto Inferior Trade." Review of Economic Studies 51, no. 1 (1984): 1-12.

Nickell, Stephen J. "Biases in Dynamic Models with Fixed Effects." Econometrica 49, no. 6 (1981): 1417-26.

North, Douglass. Structure and Change in Economic History. New York: W. W. Norton, 1981.

North, Douglass, and Barry Weingast. "Constitutions and Commitment: the Evolution of Institutions Governing Public Choice in Seventeenth-Century England.” Journal of Economic History 49, no. 4 (1989): 803-32.

Ogilvie, Sheilagh, and A.W. Carus. "Institutions and Economic Growth in Historical Perspective." In Handbook of Economic Growth, Volume 2A, edited by Philippe Aghion and Steven Durlauf, 403-513. Amsterdam: Elsevier, 2014. 
Pomeranz, Kenneth. The Great Divergence: China, Europe, and the Making of the Modern World Economy. Princeton: Princeton University Press, 2001.

Reba, Meredith, Femke Reitsma, and Karen C. Seto. "Spatializing 6,000 Years of Global Urbanization from 3700 BC to AD 2000." Scientific Data 3 (2016): 160034.

Rosenthal, Jean-Laurent. The Fruits of Revolution: Property Rights, Litigation and French Agriculture, 1700-1860. Cambridge: Cambridge University Press, 1992.

Rosenthal, Jean-Laurent, and R. Bin Wong. Before and Beyond Divergence: The Politics of Economic Change in China and Europe. Cambridge, MA: Harvard University Press, 2011.

Rowe, William T. "China: 1300-1900." In The Oxford Handbook of Cities in World History, edited by Peter Clark, 310-27. Oxford: Oxford University Press, 2013.

Shleifer, Andrei, and Robert W. Vishny. "Corruption." Quarterly Journal of Economics 108, no. 3 (1993): 599-617.

Spruyt, Hendrik. The Sovereign State and Its Competitors. Princeton: Princeton University Press, 1994.

Spufford, Peter. Power and Profit: The Merchant in Medieval Europe. London: Thames and Hudson, 2002.

Stasavage, David. "When Distance Mattered: Geographic Scale and the Development of European Representative Assemblies." American Political Science Review 104, no. 4 (2010): 625-43.

—. "Was Weber Right? The Role of Urban Autonomy in Europe's Rise." American Political Science Review 108, no. 2 (2014): 337-54.

_. "Representation and Consent: Why They Arose in Europe and Not Elsewhere." Annual Review of Political Science 19 (2016): 145-62.

Stewart, J. Q. "Empirical Mathematical Rules Concerning the Distribution and Equilibrium of Population." Geographical Review 37, no. 3 (1947): 461-85.

Studer, Roman. The Great Divergence Reconsidered. Cambridge: Cambridge University Press, 2015.

Tiebout, Charles. “A Pure Theory of Local Expenditures.” Journal of Political Economy 64, no. 5 (1956): 416-24.

van Bavel, Bas, Maarten Bosker, Eltjo Buringh, et al. "Economy." In The Oxford Handbook of Cities in World History, edited by Peter Clark, 385-402. Oxford: Oxford University Press, 2013.

van der Beek, Karine. "Political Fragmentation, Competition, and Investment Decisions: The Medieval Grinding Industry in Ponthieu, France, 1150-1250.” Economic History Review 63, no. 3 (2010): 664-87.

Vaubel, Roland. “A History of Thought on Institutional Competition.” In Institutional Competition, edited by Andreas Bergh and Rolf Hoijer, 29-66. Cheltenham: Edward Elgar, 2008.

Voigtländer, Nico, and Hans-Joachim Voth. "The Three Horsemen of Riches: Plague, War and Urbanization in Early Modern Europe." Review of Economic Studies 80, no. 2 (2012): 774-811.

Volckart, Oliver. “Central Europe's Way to a Market Economy, 1000-1800.” European Review of Economic History 6, no. 3 (2002): 309-37.

Vries, Peer. State, Economy and the Great Divergence. London: Bloomsbury, 2015. 